\title{
Does a Trawl Ban Benefit Commercially Important Decapoda and Stomatopoda in Hong Kong?
}

\author{
Lily S. R. Tao, ${ }^{1,2} \odot$ Gilbert C. S. Lui, ${ }^{3}$ Kingsley J. H. Wong, ${ }^{2}$ \\ Tommy T. Y. Hui, ${ }^{2}$ Yanny K. Y. Mak, ${ }^{2}$ Ronia C.-t Sham, ${ }^{2}$ Jason K. C. Yau, ${ }^{2}$ \\ William W. L. Cheung, ${ }^{4}$ and Kenneth M. Y. Leung ${ }^{1,2 *}$
}

\begin{abstract}
${ }^{1}$ State Key Laboratory of Marine Pollution and Department of Chemistry, City University of Hong Kong, Tat Chee Avenue, Kowloon, Hong Kong, China; ${ }^{2}$ The Swire Institute of Marine Science and School of Biological Sciences, The University of Hong Kong, Pokfulam, Hong Kong, China; ${ }^{3}$ Department of Statistics and Actuarial Sciences, The University of Hong Kong, Pokfulam, Hong Kong, China;

${ }^{4}$ Fisheries Centre, AERL, 2202 Main Mall, The University of British Columbia, Vancouver, BC V6T 1Z4, Canada
\end{abstract}

\begin{abstract}
Crustaceans were among the most valuable fishery resources in Hong Kong. However, the unrestricted and intensive use of different fishing gears, especially bottom trawling, has led to the depletion of commercially important crustaceans in Hong Kong since the 1980s. This study investigated whether commercial crustaceans recovered after the implementation of a permanent Hong Kong-wide trawl ban that began on December 31, 2012. Standardized field surveys were conducted using a commercial shrimp trawler at two sites in eastern and western waters of Hong Kong before (2004) and after the trawl ban (2013-2014 and 2015-2016) and two sites in southern waters after the trawl ban. Diversity, mean size, abundance, biomass and level of disturbance of commercial crustaceans from the three periods were investigated. The
\end{abstract}

Received 8 January 2020; accepted 30 September 2020 published online 4 November 2020

Electronic supplementary material: The online version of this article (https://doi.org/10.1007/s10021-020-00574-9) contains supplementary material, which is available to authorized users.

Author contributions: KMYL, LSRT and WWLC initiated and designed this study. LSRT, RCTS, YKYM, KJHW and JKCY conducted the experiments. LSRT and GCSL analyzed the data. TTYH improved the methods of data analyses, results interpretation and discussion. LSRT drafted the main manuscript text. KMYL and WWLC supervised the work. All authors revised and edited the manuscript.

*Corresponding author; e-mail: kmyleung@cityu.edu.hk eastern waters exhibited an increased diversity of crustacean assemblages in Inner Tolo, and a higher abundance and biomass of crabs were detected in Outer Tolo after the trawl ban. Reduced disturbance, higher diversity in crustacean assemblages and greater abundance and biomass of predatory crabs were observed after the trawl ban in the outer estuary of western waters, and increased abundance and biomass of shrimp were detected in the inner estuary of western waters. No temporal or negative changes were detected in the southeast and southern waters of Lamma Island. The various responses of crustacean assemblages in Hong Kong waters revealed the critical role of complex interactions among multiple stresses, such as ongoing reclamation works, illegal trawling activities and increased fishing efforts using other (legal) fishing methods.

Key words: trawl closures; recovery; biodiversity; coastal ecosystem; invertebrate assemblage; South China Sea. 


\section{HighLights}

- The Hong Kong SAR Government implemented a trawling ban on December 31, 2012.

- Initial signs of recovery were detected in eastern and western waters of Hong Kong.

- Site-specific responses to the ban were observed and linked to multiple stressors.

\section{INTRODUCTION}

Overexploitation of predatory fishes and restrictions on their targeting fish species have led fishermen to increasingly target invertebrates in recent decades (Pauly and others 1998; Anderson and others 2011; Eddy and others 2017). Invertebrate catches have expanded to more than 10 million tons per year globally since the 1950s (Eddy and others 2017). Among marine invertebrate fisheries, crustaceans have been the most highly-valued group since the 1970s, reaching approximately 3000 USD per ton in the 1990s (Swartz and others 2013). In particular, shrimp globally accounted for the largest part of internationally traded fishery products based on total value (approximately 15\% in 2012; FAO 2014). Among the internationally traded shrimp products, approximately $60 \%$ come from wild-caught fisheries (up to 3.4 million ton per year), with Asia as the highest yield area (Gillett 2008). Crustaceans also play an important economic role in human society and serve multiple roles as predators, herbivores, detritivores and filter feeders in marine benthic ecosystems (Anderson and others 2011). Thus, they have diverse effects on other functional groups and energy flows in the system (Eddy and others 2017).

Hong Kong's fishery resources have undergone intensive and unrestricted exploitation since the 1950s (Cheung and Sadovy 2004). Large predatory species were depleted by the 1970s, resulting in shifts in ecosystem structure, with small fishes and invertebrates forming the bulk of organisms present. Increased demand and wholesale prices of invertebrates, especially shrimp, led to increased fishing for crustaceans in local waters (Cheung and Sadovy 2004; Cheung 2015). Annual crustacean landings from Hong Kong waters peaked at 2084 tons in 1979, but declined to approximately 500 tons from 1997 onward (Cheung, 2015). Four commercially important crustacean species (Metapenaeopsis barbata, Metapenaeopsis palmensis, Oratosquilla anomala and Oratosquilla oratoria) were fully exploited in Hong Kong waters. Previous stock assessments conducted in the 1990s indicated that fishing mortality rates of these species had already exceeded the optimum level for sustainable production since the late 1970s (Pitcher and others 1998). These depletions in crustacean resources were primarily attributed to the dramatic increase in fishing efforts using bottom trawlers, which accounted for $80 \%$ of the engine power of the total fishing effort in Hong Kong (Morton 2011). In addition to the overexploitation of adults of commercial species, juveniles and a variety of noncommercial species were also caught by bottom trawlers (Sadovy 1998; Munga and others 2012). This nonselective fishing method reduced local biodiversity and caused serious destruction to benthic habitats in other parts of the world, and therefore, trawling was considered one of the most destructive fishing methods to benthic marine ecosystems (Kaiser and Spencer 1996; Tillin and others 2006; van Denderen and others 2014). To promote recovery of the seabed and associated fishery resources, the Government of the Hong Kong Special Administrative Region (HKSAR) implemented a permanent, territory-wide ban on all trawling activities on December 31, 2012 (AFCD 2011).

The effects of the implementation of trawl bans on commercial fishery resources have varied in different areas around the world. In the Scotian Shelf of Canada, the Georges Bank of the USA and the Gulf of Castellammare of Italy, several commercially important benthic fauna exhibited increased abundance and biomass after a trawl ban (Murawski and others 2000; Pipitone and others 2000; Hermsen and others 2003). Increases in catches were recorded in Indonesia and Kenya within 2 years of a trawl ban but subsequently declined due to further heavy exploitation by illegal trawling and other legal, nontrawling fishing gears (Buchary 1999; Munga and others 2012; Swaleh and others 2015). However, no positive change in abundance or biomass was reported in St. Andrews Bay or near the Offshore Wind Farm Egmond aan Zee (OWEZ), where all kinds of trawling activities were banned (Defew and others 2012; Bergman and others 2015). These varying responses to trawl bans demonstrate the effects of regional-scale drivers, such as intrinsic ecosystem structure, the effectiveness of trawl ban enforcement and the prevalence of other legal fishing efforts, in constraining ecosystem recoveries.

The present study aimed to investigate whether the abundance, biomass, diversity, level of disturbances and mean size of commercially important crustacean assemblages in Hong Kong waters 
would increase in the short term (3.5 years) after the implementation of a trawl ban. The trawl ban was expected to decrease disturbances and reduce fishing pressure on benthic ecosystems. Therefore, we hypothesized that after the trawl ban, (1) the level of disturbance on crustacean assemblage would decrease, (2) the abundance and biomass of commercially important crustacean species and predatory carnivorous crustaceans would increase and (3) the diversity, as measured by species richness and Shannon's diversity index, and mean sizes of the crustacean assemblages would increase.

\section{Materials And Methods}

\section{Field Sampling}

Sampling was conducted at two eastern sites (Inner Tolo Channel = EI, Outer Tolo = EO), two southern sites (Southeast Water $=\mathrm{SE}$, Southern Lamma Island $=\mathrm{SL}$ ), and two western sites (Inner Estuary $=\mathrm{WI}$, Outer Estuary = WO $)\left(22^{\circ} 09^{\prime} \mathrm{N}-22^{\circ} 31^{\prime}\right.$ $\mathrm{N}, 113^{\circ} 51^{\prime} \mathrm{E}-114^{\circ} 23^{\prime} \mathrm{E}$; Figure 1). The western waters of Hong Kong are influenced by the freshwater discharge from the Pearl River and have low salinity and high levels of suspended solids. The eastern waters are more oceanic and influenced by ocean currents from the Western Pacific Ocean and South China Sea, with high salinity and low levels of suspended solids. The southern waters of Hong Kong are a transitional zone where there is a mixing of freshwater from the west and oceanic water from the south and east (Morton and Morton 1983; Morton 1996; Ng and others 2016).
A scientific research permit (R1710007) for trawling was issued by the Director of Agriculture, Fisheries and Conservation Department, which enabled us to conduct the sampling using a commercial shrimp trawler after the trawl ban. Two transects were trawled at each site per survey using the commercial shrimp trawler during the day. Along each transect, the trawler (beam size: $2 \mathrm{~m}$; stretched mesh size: $2 \mathrm{~cm}$ ) with a $15-\mathrm{m}$ outrigger and ten nets towed for $30 \mathrm{~min}$ at a speed of 5$7 \mathrm{~km} / \mathrm{h}$ and covered a total trawled area of 0.0375 $0.0525 \mathrm{~km}^{2}$ per transect. In total, 49 months of surveys were conducted from December 2003 to May 2016 in the three waters (49 months in eastern and western waters starting from December 2003, and 32 months in southern waters starting from August 2012). The details of sampling months in each water zone are described in Table S1. All Decapoda and Stomatopoda specimens were returned to the laboratory and identified at the species level whenever possible (Lui and others 2007). All commercially important crustaceans were identified and counted, and body wet weights for individuals of each species were measured to the nearest $0.01 \mathrm{~g}$ using an electronic balance (HA$622 \mathrm{~N}$, Yamada). The abundance and biomass of crustacean assemblages in each transect for each survey were standardized to individuals (ind.) $/ \mathrm{km}^{2}$ for abundance and $\mathrm{kg} / \mathrm{km}^{2}$ for biomass by Equation (1):

$$
\begin{aligned}
& \text { Standardized abundance or biomass } \\
& =\text { total number or weight } / \text { (beam width } \\
& \quad * \text { number of nets } * \text { trawl distance) }
\end{aligned}
$$

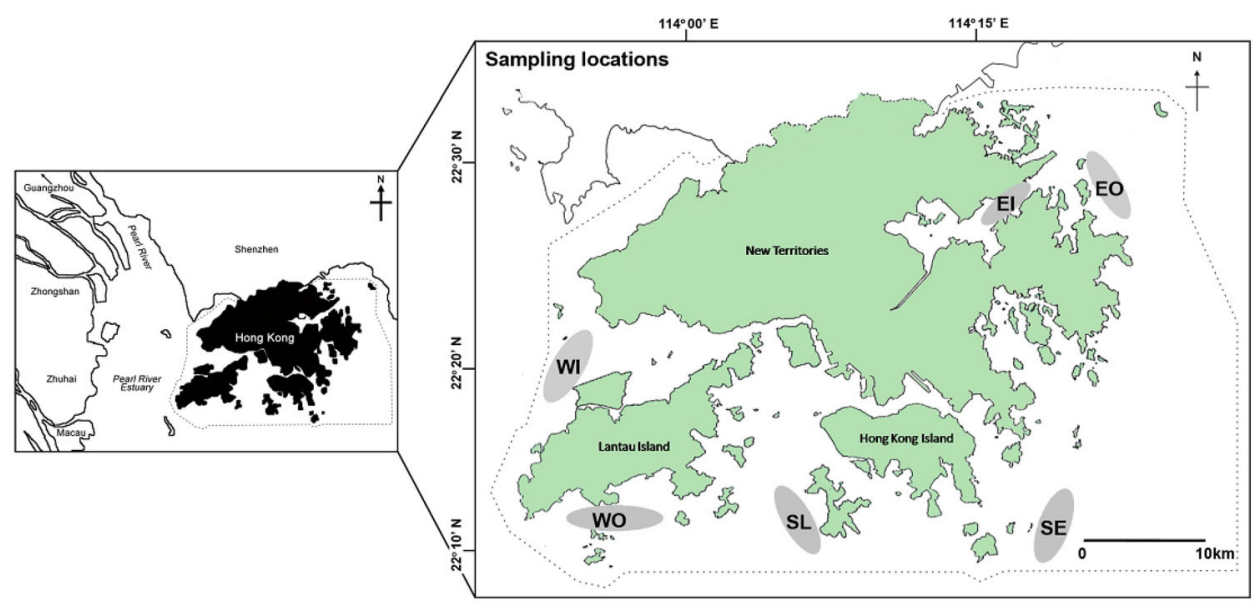

$203 \times 103 \mathrm{~mm}(300 \times 300$ DPI $)$

Figure 1. Sampling locations of benthic crustaceans in the marine environment of Hong Kong. Inner Tolo Channel (EI), Outer Tolo (EO), Southeast Water (SE), Southern Lamma Island (SL), Outer Estuary (WO) and Inner Estuary (WI). 
where the beam width was 2 meters for each net, the number of nets was 10 and trawl distance $(\mathrm{km})$ was recorded during each trawl survey using a handheld GPS device (GPSMAP-62S, Garmin).

\section{Data Analysis}

Comparison of Assemblage Structure Using Multivariate Analysis

Nonmetric multidimensional scaling ordination (nMDS) plots based on the Bray-Curtis similarity matrix were constructed to visualize spatial and interannual variations in the commercially important crustacean assemblages. Prior to calculation of the Euclidean distance dissimilarity matrix, the abundance and biomass data were $\log _{10}(x+\min (M) / 10)$ transformed, where $x$ is the raw value of abundance or biomass and $M$ is the smallest abundance or biomass value observed from the field surveys. As significantly spatial differences in commercially important crustacean assemblages were detected in a previous study (Lui and others 2007) and the present study (Figure S1), interannual differences in commercially important crustacean assemblage structure from the three periods, that are, January 2004 to December 2004 (2004; before the trawl ban), June 2013 to May 2014 (2013-2014; after the trawl ban), and June 2015 to May 2016 (2015-2016; after the trawl ban) were analyzed for each eastern and western site. Due to the limited data before the trawl ban in southern waters (SE and SL), yearly comparisons were only carried out between 2013-2014 and 2015-2016. To assess the effects of the trawl ban, a one-way permutation-based multivariate analysis of variance test (PERMANOVA; Year: fixed) was conducted to investigate interannual differences in the crustacean assemblage structure for eastern and western waters (Anderson and others 2008). The same analysis was applied to investigate the yearly variations of crustacean assemblage structure in southern waters. Prior to running the PERMANOVA, permutational tests of the homogeneity of multivariate dispersions (PERMDISP) were performed to check the homogeneity of the data. If significantly yearly differences were detected by the PERMANOVA, pairwise comparisons were subsequently conducted to identify which pairs of years were significantly different. Similarity percentages analysis (SIMPER) was performed to distinguish which species contributed to most of the differences between years in each site. All multivariate analyses were carried out using the PRIMER 6.1.5 package in PERMANOVA+ (Clarke and Gorley 2006).

\section{Comparison of Assemblage Annual Variations Using Univariate Analysis}

Interannual differences in the total abundance and biomass of commercially important crustaceans among the three surveyed years in eastern (EI and EO) and western waters (WI and WO) and between the two surveyed years in southern waters (SE and SL) were investigated at each site using Wilcoxon signed-rank test using month as the paired sample unit due to the nonnormal distribution and heterogeneous variances in the original and transformed data. Bonferroni corrections were performed to adjust the statistical significance for multiple tests in the eastern and western waters when inferring an overall difference before and after the trawl ban (Rice 1989). To test the effect of the trawl ban on different functional groups in each site, Wilcoxon signed-rank tests were used for the abundance and biomass of the three grouped taxa, namely crabs, mantis shrimp and shrimp. Specifically, species in commercially important crab and mantis shrimp groups are carnivores, and shrimp species are categorized as omnivores (Table S2).

The mean weight of the crustacean assemblage was calculated per transect per month as the total biomass of all species divided by the total abundance of individuals captured (Dulvy and others 2004; Nicholson and Jennings 2004). The diversity of the commercially important crustacean species is expressed as species richness (S) and exponential of Shannon's diversity index (EXP $H^{\prime}$ ) (Gray 2000) by estimating these indices for each transect in each month. The levels of disturbance on crustacean assemblages were identified using Warwick statistic ( $W$, Clarke 1990), which was derived from the abundance biomass curves $(\mathrm{ABC})$ proposed by Warwick (1986). W has values that range between -1 and 1 . $W$ close to 1 indicates an undisturbed ecosystem that supports high biodiversity and is dominated, in terms of biomass, by $K$-selected species, and $W$ close to -1 represents a disturbed ecosystem that only supports a low total biomass, with a higher abundance of smaller individuals (Clarke 1990). Wilcoxon tests, followed by Bonferroni corrections, were used on the above four indices to determine the effect of the trawl ban at each site separately. All univariate analyses were conducted under the $R$ environment ( $R$ version 3.3.2), and all figures were constructed using the "ggplot" package (Wickham 2009) of the R environment ( $\mathrm{R}$ Core Team 2016).

Notably, because all waters of Hong Kong had been trawled by fishing vessels in the past (AFCD 2006; Figures S2-S5 in Supplementary Informa- 
tion), it was not possible to assign a control site (that is, an area without trawling) for this study. This limitation restricted the experimental design to a before-and-after comparison without a control. We investigated the effects of the trawl ban on crustacean resources collected from eastern (EI and EO) and western waters (WI and WO) before and after the trawl ban. However, due to limited data before the trawl ban in southern waters (SE and SL), only yearly comparisons between 2013-2014 and 2015-2016 were investigated in this zone. Our results revealed an initial recovery trend in eastern and western waters, if any, and provide essential baseline data for long-term studies on spatiotemporal changes in the crustacean resources in the marine environment of Hong Kong.

\section{RESUlts}

A total of 22 decapod and nine stomatopod species of commercial importance were recorded during the entire study period. Temporal trends of the abundance, biomass and species richness of the crustaceans collected in the eastern, southern and western waters of Hong Kong are shown in Figure 2. Although there were high temporal variations in each of these parameters, increases in the biomass of total crustaceans were apparent after the trawl ban in western waters (Figure 2B).

\section{Comparison of Interannual Assemblage Structure Changes Using Multivariate Analyses}

Based on the nMDS plots of abundance and biomass data, clear separations in the crustacean assemblage structure among different years were observed in EI, EO, SL, WI and WO (Figures S6S7). The PERMANOVA results also confirmed that the crustacean assemblage structures were significantly different among years in these five sites (Tables S3-S4). Pairwise comparisons showed that the assemblage structure differed among all investigated years in the above five sites (except 20132014 vs. 2015-2016 comparison in WI; Tables S3S4).

\section{Comparison of Interannual Variations Using Univariate Analysis}

\section{Interannual Variations in the Abundance and Biomass} in Each Site

Interannual variations in the abundance and biomass in each of the six sites were observed in different taxonomic groups (that is, crabs, mantis shrimp and shrimp) (Figure 3; results of Wilcoxon test are shown in Tables S5-S6). In EI, significantly higher abundance and biomass of predatory crabs were recorded in 2013-2014 than in 2004 (Figure $3 \mathrm{~A}, \mathrm{G})$, which were ascribed to increases in the abundance and biomass of predatory crustaceans, namely Charybdis feriatus, Miyakella nepa, Portunus pelagicus/trituberculatus and a higher abundance of $P$. sanguinolentus (Figure S8). There was a significantly higher abundance of predatory crabs in EO after the trawl ban (Figure 3B), which was largely attributed to three carnivorous species, P. pelagicus/ trituberculatus and $P$. sanguinolentus (Figure S9). Significant interannual differences were also observed in predatory crabs and total crustacean biomass, with higher values recorded in 2013-2014 than 2004 (Figure 3H), which was also attributable to the three Portunus species.

No significant yearly differences were detected in SE in all four crustacean groups (Figure 3C, I), but there were significantly lower abundance and biomass of mantis shrimp and lower biomass of shrimp and total crustaceans in 2015-2016 in SL compared to 2013-2014 (Figure 3D, J). The abundance and biomass of the predatory mantis shrimp, M. nepa and Oratosquilla oratoria, decreased sharply in 2015-2016 in SL, but seven out of the nine omnivorous shrimp species decreased in biomass in 2015-2016 (Figure S10).

The abundance and biomass of predatory crabs, including C. feriatus, P. pelagicus/trituberculatus and $P$. sanguinolentus (Figure S11), increased significantly in WO after the trawl ban (Figure 3E, K). However, the abundance and biomass of shrimp increased from 2004 to 2013-2014 but declined in 2015-2016. In contrast, the abundance of predatory mantis shrimp decreased significantly in 20152016 compared to 2004 , which was largely due to a decrease in the abundance of Oratosquilla oratoria and Oratosquillina interrupta (Figure S11).

The biomass of predatory crabs in WI decreased significantly in 2015-2016, but shrimp showed a significantly higher abundance and biomass after the trawl ban (Figure 3F, I) due to a drastic increase in M. affinis (Figure S12).

Interannual Variations in Size, Biodiversity and Levels of Disturbance Indices in Each Site

The mean weight (MW), species richness (S), exponential of Shannon's diversity index $\left(\mathrm{EXP} H^{\prime}\right)$ and Warwick statistics $(W)$ are shown in Figure 4, and the Wilcoxon test results for these parameters are presented in Table S7. EXP $H^{\prime}$ and $W$ increased significantly after the trawl ban in EI. Similar 


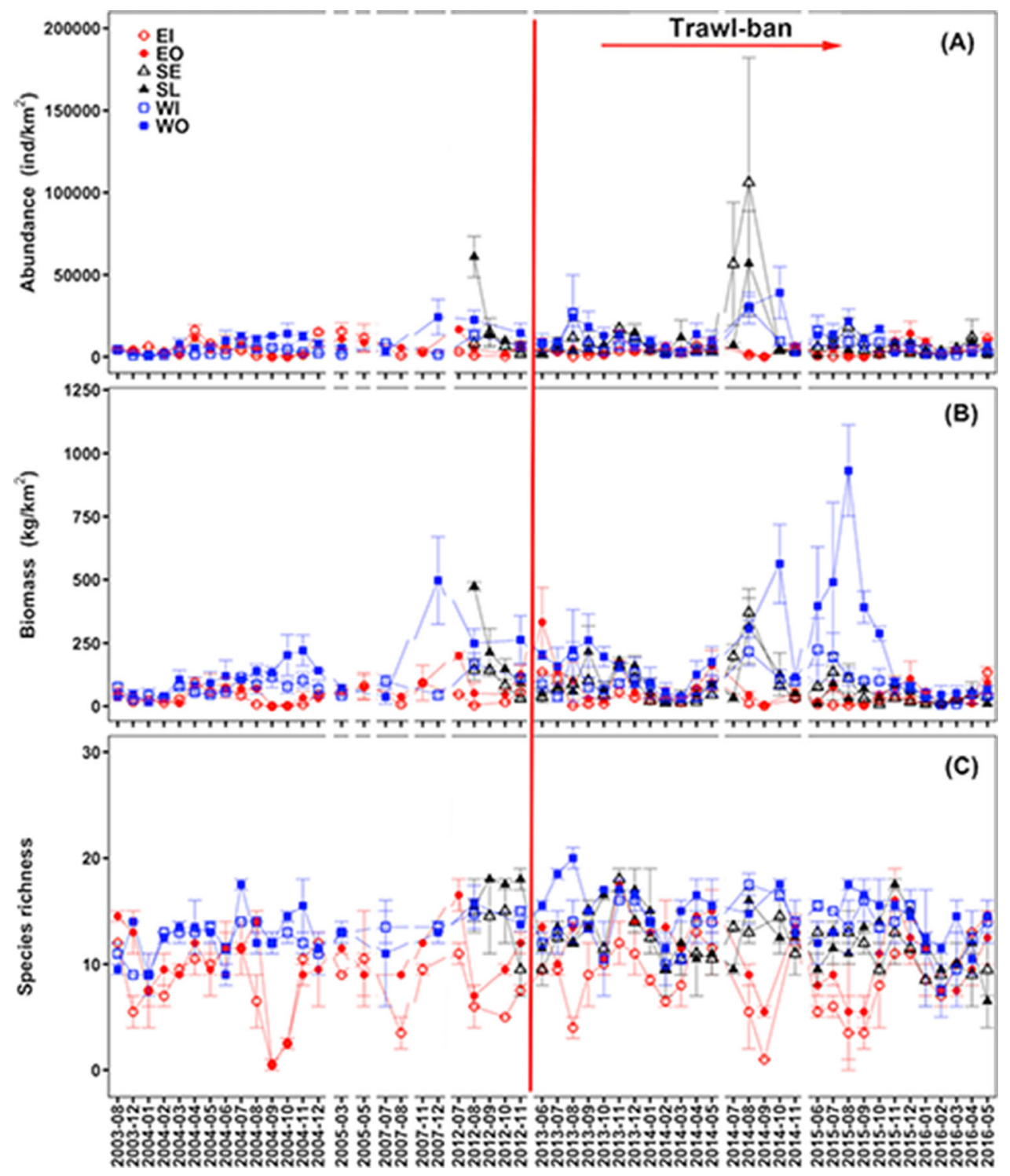

Figure 2. Monthly (A) abundance, (B) biomass and (C) species richness of all commercially important benthic crustaceans (mean \pm SEM) in EI, EO, SE, SL, WO, and WI of Hong Kong collected between August 2003 and May 2016. No data were available for SE and SL before 2012. Site abbreviations are described as: Inner Tolo Channel (EI), Outer Tolo (EO), Southeast Water (SE), Southern Lamma Island (SL), Outer Estuary (WO) and Inner Estuary (WI).

findings were recorded in EO, with significantly higher S, EXP $H^{\prime}$ and $W$ value recorded in 20132014. SE did not show any significant temporal changes in the four parameters, but SL exhibited significant decreases in these parameters in 20152016. Improved crustacean assemblages were found in WO, with significant increases in MW, higher biodiversity indices and $W$ value in 20152016. However, a significant decrease in MW was recorded in WI in 2015-2016, and no temporal differences in the other three indices were detected.

\section{Discussion}

After the banning of trawling activities, various degrees of recovery in fishery resources in previously overexploited and destructed ecosystem were reported worldwide via the measurement of various biological attributes and responses (Pipitone and others 2000; Munga and others 2012; Bergman and others 2015). Based on the results of the Ecopath and Ecosim model, Sumaila and others (2007) predicted that the biomass of benthic crustaceans would increase rapidly five years after the implementation of trawl ban in Hong Kong waters. Our 


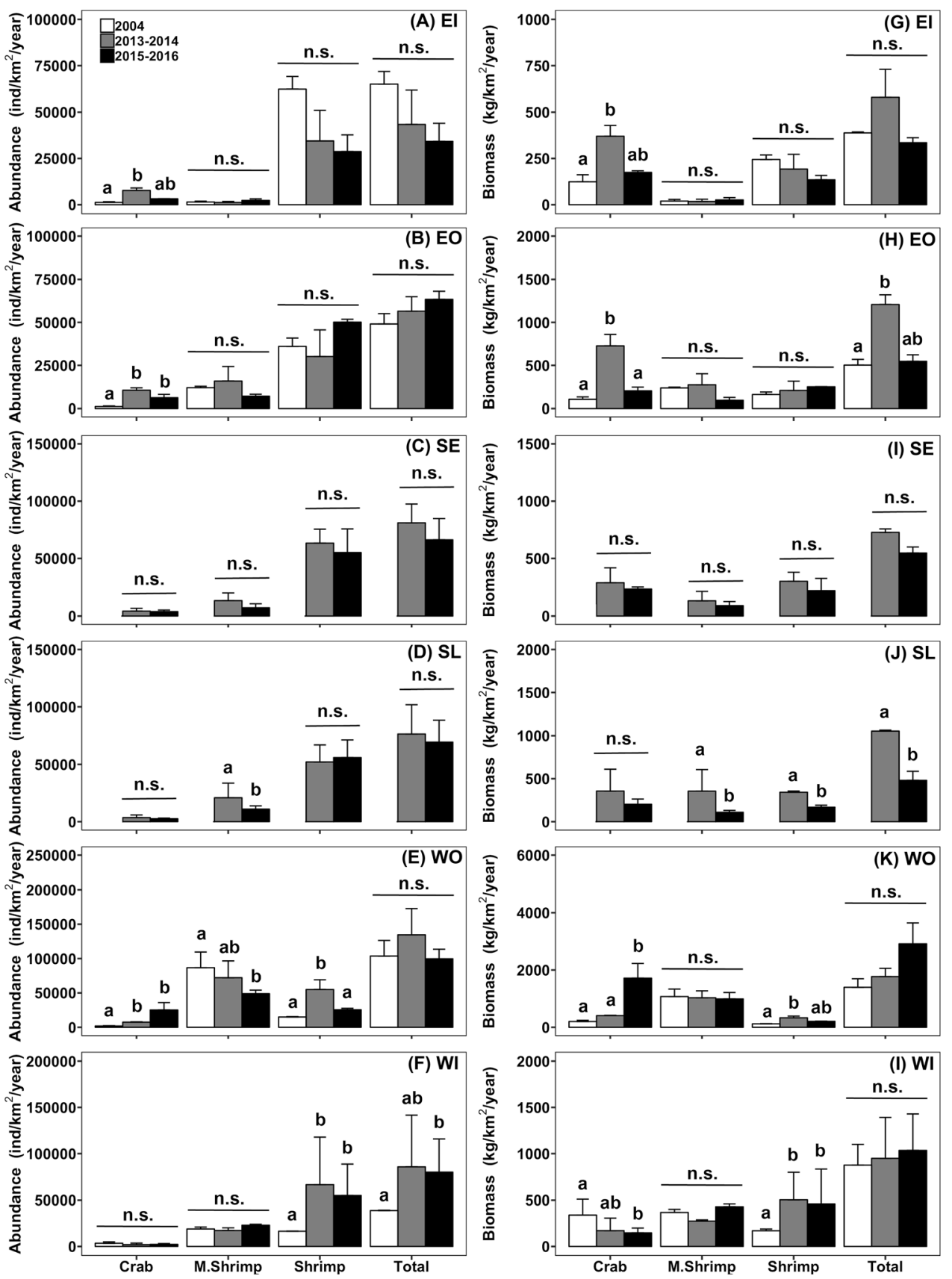

Figure 3. Temporal comparisons of mean (+ SEM) abundance (left panel; A-F) and biomass (right panel; G-L) of total crustacean, crab, mantis shrimp and shrimp species collected from the three surveyed years in EI, EO, SE, SL, WO and WI of Hong Kong. M. Shrimp represents mantis shrimp. No data were available for SE and SL in 2004. Significant differences between years are indicated by a and b, whereas no significantly difference between 3 years was marked with n.s. Site abbreviations are described as: Inner Tolo Channel (EI), Outer Tolo (EO), Southeast Water (SE), southern Lamma Island (SL), Outer Estuary (WO) and Inner Estuary (WI).

study used univariate and multivariate statistical analyses which demonstrated that the trawl ban contributed to ecosystem recoveries in eastern and western waters in the short term (3.5 years postban). Similarly, increases in the biomass and production of fishes and invertebrates were observed in Georges Bank after exclusion of fishing activities for 6 years, and a higher abundance and larger size of legal-sized lobsters were reported in Lundy Island after the establishment of a no take zone for 4 years (Murawski and others 2000; Hermsen and others 2003). Consistent with Lester and others 

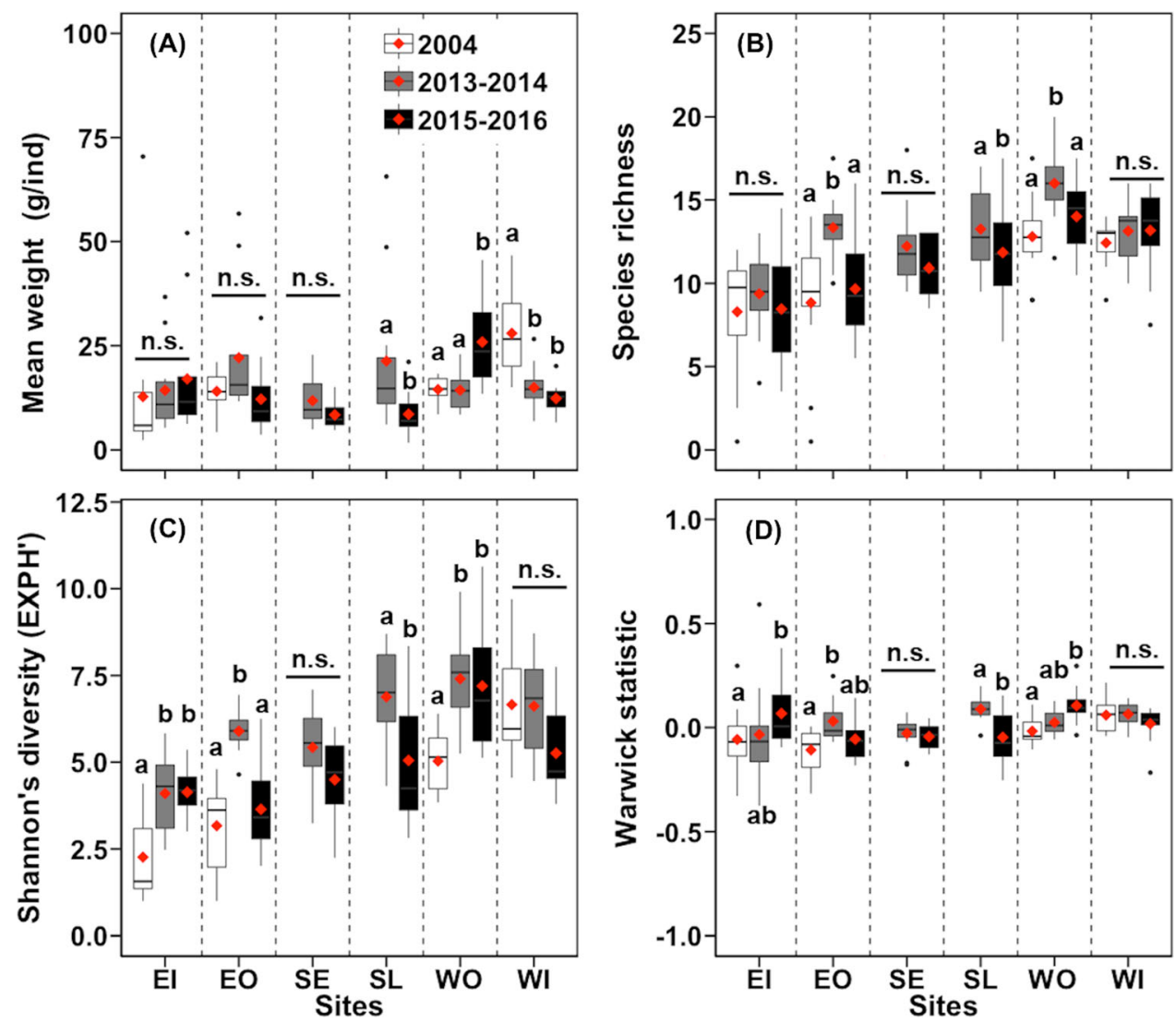

Figure 4. Mean weight (MW; A; mean + SEM), species richness ( $;$; B; mean + SEM), exponential of Shannon's diversity index (EXP H'; C; mean + SEM) and Warwick statistic ( $W$; D; mean + SEM) of commercial crustaceans collected from the three surveyed years in EI, EO, SE, SL, WO, and WI of Hong Kong. Black bar in the box indicates the median, and red diamond represents the mean of value per site per year. No data were available for SE and SL in 2004. Significant differences between years are indicated by a and b, while no significant difference between 3 years was marked with n.s. Site abbreviations are described as: Inner Tolo Channel (EI), Outer Tolo (EO), Southeast Water (SE), Southern Lamma Island (SL), Outer estuary (WO) and Inner estuary (WI).

\begin{tabular}{|c|c|c|c|c|c|c|}
\hline \multirow[b]{3}{*}{ Confounding factors } & \multicolumn{6}{|c|}{ Studied sites } \\
\hline & \multicolumn{2}{|c|}{ Eastern waters } & \multicolumn{2}{|c|}{ Southern waters } & \multicolumn{2}{|c|}{ Western waters } \\
\hline & El & EO & SE & SL & Wo & WI \\
\hline \multicolumn{7}{|c|}{ Actions and legislation to improve the water quality } \\
\hline \multicolumn{7}{|c|}{ Increases in purse seiner fishing efforts } \\
\hline \multicolumn{7}{|l|}{ Illegal trawling } \\
\hline \multicolumn{7}{|l|}{ Sea urchin blooms } \\
\hline \multicolumn{7}{|l|}{ Increases in predatory fishes } \\
\hline \multicolumn{7}{|l|}{ large-scale reclamation activities } \\
\hline & \multicolumn{6}{|c|}{ The overall trends of crustacean assemblage } \\
\hline & Sign & overy & No change & Decline & $\begin{array}{l}\text { Signs of } \\
\text { recovery }\end{array}$ & Uncertain \\
\hline
\end{tabular}

Figure 5. Confounding factors that may affect the effectiveness of the trawl ban and the overall trend of crustacean assemblage in each site after the trawl ban (based on the current results). Green color represents the factor might have positive effects on the crustacean assemblage; red color represents the factor might have negative effects on the crustacean assemblage, whereas grey color represents the factor did not have an effect on the crustacean assemblage. Site abbreviations are described as: Inner Tolo Channel (EI), Outer Tolo (EO), Southeast Water (SE), Southern Lamma Island (SL), Outer Estuary (WO) and Inner Estuary (WI). 
(2009), the present study demonstrated strong variations in crustacean assemblage recovery spatially and across functional and taxonomic groups. These findings are summarized in Figure 5 and suggest initial signs of improvement in eastern waters (EI and EO) and WO, with positive changes in most indicators, but the recovery condition is uncertain in WI, with positive and negative changes in different indicators. No changes or negative situations were recorded in southern water (SE and SL) in 2015-2016 compared with 2013-2014. These variations could be attributed to a number of factors, including biological interactions, variations in pollution status, large-scale construction works, the effectiveness of enforcement of the trawl ban and the regulation of fishing pressure from nontrawling gears (Figure 5; Hutchings 2000; Lotze and others 2011; Hiddink and others 2017; Sciberras and others 2018; Tao and others 2018).

\section{Eastern Water Zone: Inner Tolo Channel (EI) and Outer Tolo (EO)}

The marine ecosystem of the Tolo area was substantially degraded due to reclamation, polluted surface runoff from livestock farms in Tai Po and sewage discharge from an increasing population during the 1970s-1980s (Xu and others 2006), which produced regular hypoxia events each summer (Lee and Arega 1999; Lai and others 2016). Overexploited by a variety of fishing gear, fishery grounds and stocks in the Tolo and Mirs Bay areas have experienced a dramatic degradation since 1970s (Pitcher and others 2000; Xu and others 2006; Lai and others 2016).

To rehabilitate these deteriorated and impoverished marine ecosystems, a series of actions and legislation were undertaken, such as restriction on the direct release of wastewater into Tolo Harbour in 1987 (DSD 2015), exportation of sewage effluent from Tai Po and Sha Tin sewage treatment plants for discharge in the Victoria Harbour in 1998 (that is, Tolo Harbour Effluent Export Scheme), construction of sewer systems and the collection of wastewater from village houses in Tai Po for treatment in recent years (DSD 2019). These control measures remarkably improved the water quality with reduced total nitrogen and increased dissolved oxygen in bottom waters, although red tides still frequently occur in the Tolo area on an annual basis (EPD, 2018). However, our findings indicated that the abundance and biomass of carnivorous crabs, such as Portunus pelagicus, P. trituberculatus and $P$. sanguinolentus, were low despite the relatively higher DO that was recorded in 2004
(Figures S13-S14). This finding suggests that fishing activities in the Tolo area, which were as severe as trawling several times a day per square meter (Pitcher and others 2000), imposed high pressures on the crustaceans therein. Nonetheless, the trawl ban in Hong Kong waters should alleviate the fishing pressures on the benthic marine fauna community (Murawski and others 2000; Grift and others 2004) and improve the environmental conditions by reducing the probabilities of (1) churning up sediment that resuspends and releases sedimentary nitrogen into the water column, which could trigger undesirable algal blooms (Pilskaln and others 1998) and (2) shifting the surface metazoan-microbial aerobic condition into an anaerobic and turbid condition, which hampers the growth of benthos larvae, such as scallops (Yamamoto 1960; Jones 1992). With the trawl ban policy in place, it was not surprising that our study found that the abundance and biomass of carnivorous crabs, such as $P$. pelagicus, $P$. trituberculatus and $P$. sanguinolentus, increased significantly in EI and EO waters after the trawl ban (Figures S11S12). These increases were attributable to a large number of individuals of Portunus carbs in EI and EO being detected during May-July and November-January of 2013-2014 and 2015-2016 (Figures S13-S14), which suggests decreased fishing pressure after the trawl ban.

Our study found that the crustacean composition and dominant species in eastern waters changed after the implementation of the trawl ban, which is consistent with the findings of Hermsen and others (2003). The reduction of the dominant, small-sized and omnivorous shrimp species Metapenaeopsis sp. may have been the result of elevated competition pressure from increases in other penaeid species, such as Metapenaeus affinis, Penaeus latisulcatus and Parapenaeopsis tenella, and elevated predation pressure from increased predators (for example, the carnivorous Portunus crabs in our study and predatory fishes in Mak 2017) after the trawl ban. The decreases in small-sized species combined with the increases in predatory crabs contributed to the lower level of disturbance (higher $W$ values) after the trawl ban. Coupled with increased biodiversity (EXP $H^{\prime}$ ), the overall increase in these indicators (Figure 5) suggests that the ecosystem status in eastern waters improved after the trawl ban.

\section{Southern Water Zone: Southeast Water (SE) and Southern Lamma Island (SL)}

This study failed to uncover any increases in the investigated indicators in southern waters in 2015- 
2016. The lack of changes in any indicators in SE and decreases in most indicators in SL were likely linked to increases in other legal, nontrawling fishing gear after the trawl ban. However, the trawl ban policy provoked fishers into expanding their use of other legal, nontrawling fishing gear (for example, purse seine fishing, gill netting and cage trapping; AFCD 2018), which were observed more frequently during our field work after the trawl ban. There was a significant increase in fishing efforts in southern waters that operated with purse seines at night during 2013-2014, as reflected by the preliminary results of the satellite image analysis (Tao and others unpubl. data). There was also anecdotal evidence from local fishermen who claimed that they earned approximately 1.5 times more income using purse seine fishing in southern waters after the trawl ban (KMY Leung, per. commun.). These increases in legal fishing activities also compromised the positive effects of trawl bans elsewhere (Bailey 1997; Buchary 1999; Sweeting and others 2009; Mullowney and others 2012; Munga and others 2012; Swaleh and others 2015). In addition to expanding the use of nontrawling fishing gear and activities, illegal trawling, which was a notable issue in Indonesia after the trawl ban (Chong and others 1987), may be a confounding factor hindering the recovery process in the southern waters of Hong Kong (AFCD 2016).

The crustacean assemblages in SE and SL may be partially controlled by the strong biological interactions resulting from massive sea urchin blooms (primarily Temnopleuridae: Temnopleurus sp.) at southern sites after the trawl ban due to the lack of constant bottom trawling to remove them (González-Irusta and others 2014; Wong 2016). Sea urchin blooms substantially reduce food and space availabilities to other marine benthos, and it may have suspended the recovery of fish communities after the trawl ban in southern waters (Mak 2017).

\section{Western Water Zone: Outer Estuary (WO) and Inner Estuary (WI)}

Our study observed a higher diversity (increased EXP $H^{\prime}$ ) of crustacean assemblages in WO, which followed our expectation after implementation of the trawl ban (Babcock and others 1999; Worm and others 2006; Lotze and others 2011). Heath and Speirs (2011) found that the species evenness of the demersal fish community increased quickly after a seasonal trawl ban in the Firth of Clyde in southwest Scotland. Similarly, a higher ShannonWiener diversity index of the benthic community was reported in the Offshore Wind Farm Egmond aan Zee (OWEZ) 5 years after the trawl ban despite insignificant changes in the abundance and biomass of benthic organisms (Bergman and others 2015). The present study detected a general increasing trend in the total biomass of crustaceans in WO 3.5 years after the trawl ban, which is consistent with the findings of Hermsen and others (2003) who found an increased production of benthic megafauna after 5 years of closure to all bottom fishing gear. The increase in the $W$ value was marked in the WO after the trawl ban, which suggests decreased disturbances and a shifting of the crustacean assemblage that was initially dominated by a few small-sized species to a status dominated by a few large-sized species (Clarke and Warwick 1994). These increases were primarily attributed to an expansion of predatory crabs, which subsequently elevated the mean size of crustacean assemblages in the WO and were expected to increase under low fishing pressure (Worm and others 2009). Similar patterns were observed in fish communities with increases in the abundance and biomass of fish, especially large, predatory fish, after a trawl ban (Mak 2017; Tao and others 2018).

Nevertheless, the results observed in the WI were somewhat different from the WO. There were significant increases in total crustaceans in the WI, particularly shrimp, after the trawl ban. The increased abundance and biomass of omnivorous shrimp were largely attributed to Metapenaeus affinis, which have a short life span (Leena and Deshmukh 2009) and high market value (Holthuis 1980). A similar increase in the production of omnivorous invertebrates was reported in the Georges Bank of North America, with a higher production of sea urchins (Strongylocentrotus droebachiensis), 6 years after a trawl ban (Hermsen and others 2003). Commercial scallop (Placopecten magellanicus) stocks also benefited from 4 years of the closure of fishing activities, with a 15 -fold increase in commercial-sized sea scallops (Murawski and others 2000). However, the biomass of predatory crabs decreased significantly after the trawl ban in the present study, which may be attributed to the increased abundance and biomass of predatory fishes in WI, which imposed strong competition among these species (Mak 2017). These responses are in agreement with the findings of Hoskin and others (2011) who documented that the abundance of the velvet crab Necora puber decreased in the No Take Zone (NTZ) of Lundy Island in the UK after a 4-year closure and was suppressed by the increased abundance of the lobster Homarus gammarus. Other than the biological factors that hinder 
recovery, there are a number of ongoing local disturbances to the benthic marine communities in the western waters of Hong Kong, including illegal trawling (AFCD 2016), large-scale reclamation activities associated with the construction of the Hong Kong-Zhuhai-Macau Bridge and the Third Runway System at the Hong Kong International Airport and busy marine traffic (Highway Department 2015; HKIA 2015; Lai and others 2016). These construction works, which involve reclamation of a large area of the seabed (for example, 650 ha for the Third Runway), remove benthic habitats, occasionally release contaminants from the seabed and generate noise, which impose major threats to local marine biodiversity and likely hinder the ecosystem recovery brought by the trawl ban (Lotze and others 2006; Liu 2013).

Previous studies on the effects of closure to trawling and/or all fishing activities suggested that management interventions may be more efficacious in tropical ecosystems than temperate regions. As species living in tropics tend to have short life spans, fast growth rates and mature at a younger age than temperate species, ecosystem recoveries are expected to be faster in tropical than temperate regions (McConnell and Lowe-McConnell 1987; Link and others 2011; Breen and others 2015; Kincaid and Rose 2017). Our study is consistent with the above findings and demonstrated positive responses in crustacean assemblages after 3.5 years of the trawl ban in eastern and western waters of subtropical Hong Kong. These positive responses in the short term are consistent with previous meta-analysis findings (Hiddink and others 2017; Sciberras and others 2018) and empirical studies (Hermsen and others 2003; Hoskin and others 2011; Bergman and others 2015), which denoted post-trawling recovery times that ranged from a few months to 6.4 years. However, the current study also demonstrated that the effects of the trawl ban were spatially variable, which indicates the important role of regional-scale processes, such as large-scale construction works, biotic interaction in driving the recoveries of marine benthic community and the effectiveness of law enforcement and fisheries management. Therefore, long-term monitoring across multiple regions within the territory is needed to further evaluate the effectiveness of the trawl ban in the long run.

\section{ConClusion}

The present study observed site-specific responses to the trawl ban on commercially important crustacean assemblages in Hong Kong waters. Signs of improvement in these crustaceans were detected in eastern and western waters of Hong Kong after 3.5 years of the trawl ban. No yearly differences or decreased trends were recorded in the southern waters between the two investigated years after the trawl ban. These spatial variations in the response to the ban are likely attributable to differences in the food-web structure, anthropogenic disturbances, fishing pressure using legal methods and ongoing construction works across sites. The current results only represent short-term responses of the trawl ban, and long-term studies are essential to ascertain the full recovery and understand the extent of the recovery. To better understand changes in the food-web structures and functioning, we advocate the use of other techniques, such as stable isotope analysis and mass-balance-based modeling approaches (for example, Ecopath and Ecosim (Pauly and others 2000)), for more comprehensive assessments of ecosystem responses to the management interventions (that is, the trawl ban) and the presence of anthropogenic disturbances.

\section{ACKNOWLEDGEMENTS}

This research was substantially funded by the Research Grants Council of the Hong Kong SAR Government via its Collaborative Research Fund (Project No.: HKU5/CRF/12G) to Kenneth Leung. Lily Tao, Yanny Mak, Ronia C.T. Sham and Jason Yau thanked the University of Hong Kong (HKU) for partially funding their PhD studies. The authors sincerely thank Ms. Helen Leung for her technical support and Dr. S.F. Leung, Director of Agriculture, Fisheries and Conservation Department, for granting us a scientific research permit (R1710007) for conducting the sample collection using a shrimp trawler.

\section{Compliance with Ethical Standards}

Conflict of interest The authors declare that they have no competing interests.

\section{OPEN ACCESS}

This article is licensed under a Creative Commons Attribution 4.0 International License, which permits use, sharing, adaptation, distribution and reproduction in any medium or format, as long as you give appropriate credit to the original author(s) and the source, provide a link to the Creative Commons licence, and indicate if changes were made. The images or other third party material in 
this article are included in the article's Creative Commons licence, unless indicated otherwise in a credit line to the material. If material is not included in the article's Creative Commons licence and your intended use is not permitted by statutory regulation or exceeds the permitted use, you will need to obtain permission directly from the copyright holder. To view a copy of this licence, visit $h$ ttp://creativecommons.org/licenses/by/4.0/.

\section{REFERENCES}

AFCD Agriculture Fisheries and Conservation Department. 2006. Port Survey 2006. Agriculture Fisheries and Conservation Department. The Government of the Hong Kong Special Administrative Region, Hong Kong, China

AFCD Agriculture Fisheries and Conservation Department. 2011. Legislative Proposals to Take Forward the Trawl Ban and Other Fisheries Management Measures. (accessed 26 November 2016). Available from: https://www.afcd.gov.hk/e nglish/fisheries/fish_cap/fish_cap_con/files/LEGOEng.pdf

AFCD. 2016. Progress Update on the Promotion of Sustainable Fisheries Development. (accessed 26 November 2016). Available from: http://www.legco.gov.hk/yr15-16/english/pa nels/fseh/papers/fseh20160510cb2-1419-5-e.pdf

AFCD. 2018. Department Annual report. (accessed 7 May 2019). Available from: https://www.afcd.gov.hk/english/publication s/publications_dep/publications_dep.html

Anderson M, Gorley RN, Clarke RK. 2008. Permanova+ for Primer: Guide to Software and Statistical Methods. Plymouth: PRIMER-E Ltd. p 218.

Anderson SC, Flemming JM, Watson R, Lotze HK. 2011. Rapid global expansion of invertebrate fisheries: trends, drivers, and ecosystem effects. PLoS One 6:e14735.

Babcock RC, Kelly S, Shears NT, Walker JW, Willis TJ. 1999. Changes in community structure in temperate marine reserves. Marine Ecology Progress Series 189:125-34.

Bailey C. 1997. Lessons from Indonesia's 1980 trawler ban. Marine Policy 21:225-35.

Bergman MJN, Ubels SM, Duineveld GCA, Meesters EWG. 2015. Effects of a 5-year trawling ban on the local benthic community in a wind farm in the Dutch coastal zone. ICES Journal of Marine Science 72:962-72.

Breen P, Posen P, Righton D. 2015. Temperate marine protected areas and highly mobile fish: a review. Ocean and Coastal Management 105:75-83.

Buchary E. 1999. Evaluating the effect of the 1980 trawl ban in the Java Sea, Indonesia: an ecosystem-based approach. M.Sc. thesis, University of British Columbia, Vancouver, British Columbia, Canada. 143p.

Cheung WWL, Sadovy Y. 2004. Retrospective evaluation of data-limited fisheries: a case from Hong Kong. Reviews in Fish Biology and Fisheries 14:181-206.

Cheung WWL. 2015. Reconstructed catches in waters administrated by the Hong Kong Special Administrative Region. Fisheries Centre Working Paper \#2015-93, University of British Columbia, Vancouver, Canada. 16p.

Chong KC, Dwiponggo A, Ilyas S, Martosubroto P. 1987. Some experiences and highlights of the Indonesian trawl ban: bioeconomics and socioeconomics. InIndo Pacific Fisheries Commission, Papers presented at the Symposium on
Exploitation and Management of Marine Fishery Resources in Southeast Asia held in conjunction with the Twenty-Second Session of the Indo-Pacific Fishery Commission, Darwin, Australia. pp 16-26.

Clarke KR, Gorley RN. 2006. Primer v6: User manual/tutorial. Plymouth: PRIMER-E Ltd. p 190p.

Clarke KR, Warwick RM. 1994. Change in marine communities: an approach to statistical analysis and interpretation. Plymouth: PRIMER-E Ltd. p 176p.

Clarke KR. 1990. Comparisons of dominance curves. Journal of Experimental Marine Biology and Ecology 138:143-57.

Defew E, Wood C, Bates R, Wilson L, Wilson J. 2012. An assessment of the potential impact of No-take Zones upon benthic habitats: a case study from SE Scotland. The Crown Estate. 37p. ISBN: 978-1-906410-33-9.

DSD Drainage Services Department. 2015. Sewage services and harbour area treatment. In: Janet L. Scott editor. Going the Extra Miles. Hong Kong: China, Government Logistics Department of the Government of the Hong Kong Special Administrative Region. pp 30-65.

DSD Drainage Services Department. 2019. DSD Annual Media Briefing 2019. (accessed 7 May 2019). Available from: https:// www.dsd.gov.hk/mobile/EN/Publicity_and_Publications/Med ia_interview/news3864.html

Dulvy NK, Polunin NVC, Mill AC, Graham NAJ. 2004. Size structural change in lightly exploited coral reef fish communities: evidence for weak indirect effects. Canadian Journal of Fisheries and Aquatic Sciences 61:466-75.

Eddy TD, Lotze HK, Fulton EA, Coll M, Ainsworth CH, Araújo JN, Bulman CM, Bundy A, Christensen V, Field JC, Gribble NA, Hasan M, Mackinson S, Townsend H. 2017. Ecosystem effects of invertebrate fisheries. Fish and Fisheries 18:40-53.

EPD Environmental Protection Department. 2018. Marine water quality in Hong Kong in 2017. (accessed 7 May 2019). https:// www.epd.gov.hk/epd/sites/default/files/epd/english/envir onmentinhk/water/hkwqrc/files/waterquality/annual-report/ marinereport2017.pdf

FAO Food and Agriculture Organization. 2014. The State of World Fisheries and Aquaculture-Opportunities and Challenges. Food and Agriculture Organisation of the United Nations, Rome, Italy

Gillett R. 2008. Global study of shrimp fisheries. Food and Agriculture Organization of the United Nations, Fisheries Technical Paper. No. 475. Rome, FAO. 331p.

González-Irusta JM, Preciado I, López-López L, Punzón A, Cartes JE, Serrano A. 2014. Trawling disturbance on the isotopic signature of a structure-building species, the sea urchin Gracilechinus acutus (Lamarck, 1816). Deep Sea Research Part II: Topical Studies in Oceanography 106:216-24.

Gray JS. 2000. The measurement of marine species diversity, with an application to the benthic fauna of the Norwegian continental shelf. Journal of Experimental Marine Biology and Ecology 250:23-49.

Grift RE, Tulp I, Clarke L, Damm U, McLay A, Reeves S, Vigneau J, Weber W. 2004. Assessment of the ecological effects of the Plaice Box. Report of the European Commission Expert Working Group to evaluate the Shetland and Plaice boxes. Brussels. $121 \mathrm{p}$

Heath MR, Speirs DC. 2011. Changes in species diversity and size composition in the Firth of Clyde demersal fish community (1927-2009). Proceedings of the Royal Society of London B: Biological Sciences 279:543-53. 
Hermsen JM, Collie JS, Valentine PC. 2003. Mobile fishing gear reduces benthic megafaunal production on Georges Bank. Marine Ecology Progress Series 260:97-108.

Hiddink JG, Jennings S, Sciberras M, Szostek CL, Hughes KM, Ellis N, Rijnsdorp AD, McConnaughey RA, Mazor T, Hilborn R, Collie JS, Pitcher CR, Amoroso RO, Parma AM, Suuronen P, Kaiser MJ. 2017. Global analysis of depletion and recovery of seabed biota after bottom trawling disturbance. Proceedings of the National Academy of Sciences of the United States of America 114:8301-6.

Highway Department. 2015. Hong Kong-Zhuhai-Macau Bridge (HZMB). (accessed 7 May 2019). http://www.hzmb.hk/eng/ index.html

HKIA Hong Kong International Airport. 2015. Three runway system. (accessed 7 May 2019). http://www.threerunwaysys tem.com/en/

Holthuis LB. 1980. FAO species catalogue. Volume 1. Shrimps and prawns of the world. An annotated catalogue of species of interest to fisheries. No. 125. Rome, FAO. 271p.

Hoskin MG, Coleman RA, Von Carlshausen E, Davis CM. 2011. Variable population responses by large decapod crustaceans to the establishment of a temperate marine no-take zone. Canadian Journal of Fisheries and Aquatic Sciences 68:185200.

Hutchings JA. 2000. Collapse and recovery of marine fishes. Nature 406:882-5.

Jones JB. 1992. Environmental impact of trawling on the seabed: a review. New Zealand Journal of Marine and Freshwater Research 26:59-67.

Kaiser MJ, Spencer BE. 1996. The effects of beam-trawl disturbance on infaunal communities in different habitats. Journal of Animal Ecology: 348-58.

Kincaid K, Rose G. 2017. Effects of closing bottom trawling on fisheries, biodiversity, and fishing communities in a boreal marine ecosystem: the Hawke Box off Labrador, Canada. Canadian Journal of Fisheries and Aquatic Sciences 74:1490502.

Lai RWS, Perkins MJ, Ho KKY, Astudillo JC, Yung MMN, Russell BD, Williams GA, Leung KMY. 2016. Hong Kong's marine environments: history, challenges and opportunities. Regional Studies in Marine Science 8:259-73.

Lee JH, Arega F. 1999. Eutrophication dynamics of Tolo Harbour, Hong Kong. Marine Pollution Bulletin 39:187-92.

Leena K, Deshmukh VD. 2009. Age and growth of Jhinga prawn Metapenaeus affinis Milne Edwards (Decapoda, Penaeidae) in Mumbai waters. Indian Journal of Fisheries 56:1-5.

Lester SE, Halpern BS, Grorud-Colvert K, Lubchenco J, Ruttenberg BI, Gaines SD, Airamé S, Warner RR. 2009. Biological effects within no-take marine reserves: a global synthesis. Marine Ecology Progress Series 384:33-46.

Link JS, Bundy A, Overholtz WJ, Shackell N, Manderson J, Duplisea D, Hare J, Koen-Alonso M, Friedland KD. 2011. Ecosystem-based fisheries management in the Northwest Atlantic. Fish and Fisheries 12:152-70.

Liu JY. 2013. Status of marine biodiversity of the China Seas. PLoS One 8:e50719.

Lotze HK, Coll M, Magera AM, Ward-Paige C, Airoldi L. 2011. Recovery of marine animal populations and ecosystems. Trends in Ecology and Evolution 26:595-605.

Lotze HK, Lenihan HS, Bourque BJ, Bradbury RH, Cooke RG, Kay MC, Kidwell SM, Kirby MX, Peterson CH, Jackson JBC.
2006. Depletion, degradation, and recovery potential of estuaries and coastal seas. Science 312:1806-9.

Lui KKY, Ng JSS, Leung KMY. 2007. Spatio-temporal variations in the diversity and abundance of commercially important Decapoda and Stomatopoda in subtropical Hong Kong waters. Estuarine, Coastal and Shelf Science 72:635-47.

Mak YKY. 2017. Effects of trawl ban on demersal fish communities in the marine environment of Hong Kong, South China. Ph.D. thesis, The University of Hong Kong, Hong Kong, China. $334 \mathrm{p}$.

McConnell R, Lowe-McConnell R. 1987. Ecological studies in tropical fish communities. New York: Cambridge University Press.

Morton B, Morton J. 1983. The Sea Shore Ecology of Hong Kong. Hong Kong: Hong Kong University Press. p 450p.

Morton B. 1996. The subsidiary impacts of dredging (and trawling) on a subtidal benthic molluscan community in the southern waters of Hong Kong. Marine Pollution Bulletin 32:701-10.

Morton B. 2011 . At last, a trawling ban for Hong Kong's inshore waters. Marine Pollution Bulletin 62:1153-4.

Mullowney DRJ, Morris CJ, Dawe EG, Skanes KR. 2012. Impacts of a bottom trawling exclusion zone on Snow Crab abundance and fish harvester behavior in the Labrador Sea, Canada. Marine Policy 36:567-75.

Munga C, Ndegwa S, Fulanda B, Manyala J, Kimani E, Ohtomi J, Vanreusel A. 2012. Bottom shrimp trawling impacts on species distribution and fishery dynamics; Ungwana Bay fishery Kenya before and after the 2006 trawl ban. Fisheries Science 78:209-19.

Murawski SA, Brown R, Lai HL, Rago PJ, Hendrickson L. 2000. Large-scale closed areas as a fishery-management tool in temperate marine systems: the Georges Bank experience. Bulletin of Marine Science 66:775-98.

Ng TPT, Cheng MCF, Ho KKY, Lui GCS, Leung KMY, Williams GA. 2016. Hong Kong's rich marine biodiversity: the unseen wealth of South China's megalopolis. Biodiversity and Conservation 26:1-14.

Nicholson MD, Jennings S. 2004. Testing candidate indicators to support ecosystem-based management: the power of monitoring surveys to detect temporal trends in fish community metrics. ICES Journal of Marine Science 61:35-42.

Pauly D, Christensen V, Dalsgaard J, Froese R, Torres F Jr. 1998. Fishing down marine food webs. Science 279:860-3.

Pauly D, Christensen V, Walters C. 2000. Ecopath, Ecosim, and Ecospace as tools for evaluating ecosystem impact of fisheries. ICES Journal of Marine Science: Journal du Conseil 57:697706

Pilskaln CH, Churchill JH, Mayer LM. 1998. Resuspension of sediment by bottom trawling in the Gulf of Maine and potential geochemical consequences. Conservation Biology $12: 1223-9$.

Pipitone C, Badalamenti F, D'Anna G, Patti B. 2000. Fish biomass increase after a four-year trawl ban in the Gulf of Castellammare (NW Sicily, Mediterranean Sea). Fisheries Research 48:23-30.

Pitcher TJ, Watson R, Courtney A, Pauly D. 1998. Assessment of Hong Kong's inshore fishery resources. Fisheries Centre Research Reports, Fisheries Centre, University of British Columbia, Vancouver, British Columbia, Canada. 6(1):148p.

Pitcher TJ, Watson R, Haggan N, Guénette S, Kennish R, Sumaila UR, Cook D, Wilson K, Leung A. 2000. Marine reserves 
and the restoration of fisheries and marine ecosystems in the South China Sea. Bulletin of Marine Science 66:543-66.

R Core Team. 2016. R: A language and environment for statistical computing. R Foundation for Statistical Comuputing, Vienna, Austria. http://www.R-project.org.

Rice WR. 1989. Analyzing tables of statistical tests. Evolution 43:223-5.

Sadovy Y. 1998. Patterns of reproduction in marine fishes of Hong Kong and adjacent waters. In: Morton B, editor. The marine biology of the South China Sea. Proceedings of the Third International Conference of the Marine Biology of the South China Sea. Hong Kong: Hong Kong University Press. pp 261-74.

Sciberras M, Hiddink JG, Jennings S, Szostek CL, Hughes KM, Kneafsey B, Clarke LJ, Ellis N, Rijnsdorp AD, McConnaughey RA, Hilborn R, Collie JS, Pitcher CR, Amoroso RO, Parma AM, Suuronen P, Kaiser MJ. 2018. Response of benthic fauna to experimental bottom fishing: a global meta-analysis. Fish and Fisheries 19:698-715.

Sumaila UR, Cheung WW, Teh L. 2007. Rebuilding Hong Kong's marine fisheries: an evaluation of management options. Fisheries Centre Research Report, University of British Columbia, Vancouver, British Columbia, Canada. 15(3):149p.

Swaleh K, Kaunda-Arara B, Ruwa R, Raburu P. 2015. Ecosystem-based assessment of a prawn fishery in coastal Kenya using ecological indicators. Ecological Indicators 50:233-41.

Swartz W, Sumaila R, Watson R. 2013. Global ex-vessel fish price database revisited: a new approach for estimating 'missing'prices. Environmental and Resource Economics 56:467-80.

Sweeting CJ, Badalamenti F, D'Anna G, Pipitone C, Polunin NVC. 2009. Steeper biomass spectra of demersal fish communities after trawler exclusion in Sicily. ICES Journal of Marine Science 66:195-202.

Tao LSR, Lui KKY, Lau ETC, Ho KKY, Mak YKY, de Mitcheson YS, Leung KMY. 2018. Trawl ban in a heavily exploited marine environment: responses in population dynamics of four stomatopod species. Scientific reports 8:17876.

Tillin HM, Hiddink JG, Jennings S, Kaiser MJ. 2006. Chronic bottom trawling alters the functional composition of benthic invertebrate communities on a sea-basin scale. Marine Ecology Progress Series 318:31-45.

van Denderen PD, Hintzen NT, Rijnsdorp AD, Ruardij P, van Kooten T. 2014. Habitat-specific effects of fishing disturbance on benthic species richness in marine soft sediments. Ecosystems 17:1216-26.

Warwick RM. 1986. A new method for detecting pollution effects on marine macrobenthic communities. Marine Biology 92:557-62.

Wickham H. 2009. GGplot2: elegant graphics for data analysis. New York: Springer.

Wong TL. 2016. Ecology and biodiversity of benthic marine molluscs before and after the 2012 trawling ban in Hong Kong. M.Phil. thesis, The University of Hong Kong, Hong Kong, China. 281p.

Worm B, Barbier EB, Beaumont N, Duffy JE, Folke C, Halpern BS, Jackson JBC, Lotze HK, Micheli F, Palumbi SR, Sala E, Selkoe KA, Stachowicz JJ, Watson R. 2006. Impacts of biodiversity loss on ocean ecosystem services. Science 314:78790.

Worm B, Hilborn R, Baum JK, Branch TA, Collie JS, Costello C, Fogarty MJ, Fulton EA, Hutchings JA, Jennings $S$, Jensen OP, Lotze HK, Mace PM, McClanahan TR, Minto C, Palumbi SR, Parma AM, Ricard D, Rosenberg AA, Watson R, Zeller D. 2009. Rebuilding global fisheries. Science 325:578-85.

Xu FL, Hao JY, Tao S, Dawson RW, Lam KC, Chen YD. 2006. Restoration of marine coastal ecosystem health as a new goal for integrated catchment management in Tolo Harbor, Hong Kong, China. Environmental Management 37:540-52.

Yamamoto G. 1960. Mortalities of the scallop during its life cycle. Bulletin of the Marine Biological Station at Asamushi 10:14952. 